\title{
Prologue: I Was a Tourist at Freud House, London
}

In the spring of 2007, Juliet Flower MacCannell and I stopped over in London for ten days between lectures. Our son Daniel and his friend Eleanor Hayes came down from Scotland to stay with us in a rented flat. On our second to last night we were guests at a dinner hosted by the London University Cassal Lecture Committee. Someone asked how we would spend our last day in London. "We are going to see Freud's house," I answered.

A dinner companion interjected, "Unfortunately tomorrow is Tuesday and the Freud House Museum is closed."

Twenty years before, Daniel and his younger brother, Jason, went without me to visit the Freud House in Hampstead. They were in their early teens and reported their experience with unalloyed enthusiasm. My schedule did not permit me to go then or on subsequent trips to London. Over the next twenty years, Freud and psychoanalytic theory had grown in importance for my studies. ${ }^{1}$ I wanted to see for myself how the Freud House had touched the sensibilities of two American teenaged boys.

My disappointment on being told I would again miss the Freud House must have been palpable. My dinner companion immediately reassured me that as director of research at the Freud House Museum he could meet us there and open it for a private tour. My new friend, Michael Molnar, watches over the museum and its archives with an expert eye. We met him and his colleague Rita Apsan at the House the next afternoon. They unlocked the doors, took down the velvet cords, and turned off the electronic 
protections so we could approach the objects and move freely without setting off alarms.

Before stepping across the threshold, I knew well the circumstances of Freud's London residence in I938, the last year of his life. Soon after the Nazis invaded Austria they began to intimidate Freud with interrogations, demands to search his home and office, and a harrowing detention of his daughter Anna. Huge effort and luck went into obtaining the official German declaration that Freud was Unbedenklichkeitserklärung (innocuous) allowing him, his wife, Martha, and Anna to leave. ${ }^{2}$ They were granted exit documents despite the mutual loathing of psychoanalysis and Fascism and the not incidental matter of Freud's Jewish birth. ${ }^{3}$ Ernest Jones, his eventual biographer, convinced England to grant asylum. Freud's disciple, Princess Marie Bonaparte, paid the substantial Nazi ransom. Any number of factors might have led to a different, horrific ending. William Bullitt, then the U.S. ambassador to France, had been psychoanalyzed by Freud in the I 920 s and was Freud's collaborator for a study of Woodrow Wilson. ${ }^{4}$ Coincidentally, Bullitt was a close friend both to Freud and to Franklin Roosevelt. No more favorable alignment can be imagined. At Bullitt's urging, the United States, not yet at war with Germany, successfully pressured Berlin to release Freud, his family, and belongings.

The papers, library, furniture (including the famous couch and his writing desk), and his collection of antiquities were moved from I9 Berggasse in Vienna to 20 Maresfield Gardens in London in early summer 1938. Freud glossed his departure and exile as the realization of his "desire to die in freedom." 5 Anna Freud continued to live, write, and practice psychotherapy at this address until her death in I982. Anna preserved Freud's study and consulting room, couch, library, pictures on the walls, et cetera, as her father arranged them. This is what the visitor sees today.

When I entered, I saw immediately what had so impressed Daniel and Jason twenty years before. A vast collection of ancient miniature Greek, Roman, Egyptian, and Chinese figures arranged in promiscuous and fanciful groupings cover almost every available surface. Small-scale men, women, animals, and deities stand attentively on his desk like an audience awaiting his next word. On tables and shelves were intimate conversational groupings, others lined up parade style, and still others faced off as if in battle.

Throughout their childhood, our sons collected and played with miniature Napoleonic armies; Fisher-Price Adventure People; Britain's Limited barnyard figures and wild animals; Tintin, Snowy and Captain Haddock; 
cowboys and Indians; Star Wars; Dungeons and Dragons, and Warner Brothers and Marvel cartoon figures. The groupings of miniatures in Freud's study were uncannily familiar, both formally and logically similar to arrangements my children endlessly created in every corner of our house. Only Freud's “action figures" included Thoth conversing with Athena, not Curious George, Bugs Bunny, and Wonder Woman. Through the eyes of my young sons, Freud must have appeared as a big kid, someone who would be fun to play with, someone with really cool toys.

\section{FREUD'S GHOSTS}

Freud surrounded himself with antiquities and ghosts. They, or their symbolic representatives, are still there and his spirit is among them. ${ }^{6}$ Near the couch on the writing desk his reading glasses and pen rest on an unfinished handwritten page as if he just stepped away, perhaps to return at any moment.

Later Rita and Michael served us tea and biscuits in Anna's study. When she was in London making The Prince and the Showgirl, Marilyn Monroe consulted with Anna in this room. Juliet sat on the couch where Marilyn sat. I mentioned how kindly I thought it was for Freud to leave us with the thought that he had "died in freedom," when the truth of the matter is more nuanced. Freud was an ardent anti-Fascist who died before the outcome of the Second World War was evident. He died not knowing Hitler would lose, not knowing if the brief moment of freedom he found was about to be snuffed out for everyone. This is reason enough for his ghost to hang around. My son Jason recently remarked to me, "Death must be like having to leave an excellent movie partway through, never knowing how it ends, with no possibility of catching a rerun."

The reason I start this book with my tour of the Freud House is the special exhibit mounted at the time. Molnar had mined a rich vein in the Freud archive, little known and less discussed. "Freud the Traveler" consisted of souvenirs from trips abroad, postcards and letters containing his observations of foreign peoples and places, and quotes referencing his sightseeing in his better-known writings. Many of the figurines were souvenirs purchased abroad. Here are fragments of the signage at the "Freud's Wanderlust" display: "his travels are a form of dreamwork. ... fulfill[ing] childhood wishes of discovery and conquest. . . . Once on a train in Italy he met his double, an aging stranger."

One need only reopen The Interpretation of Dreams to see how important travel was to Freud and psychoanalytic theory. He devotes 
pages to his own dreams of being in Rome, dreamt before he ever went there. His unalloyed enthusiasm for the parallel between the unconscious and places unvisited is evident throughout: "Paris ... had for many long years been another goal of my longings; and the blissful feelings with which I first set foot on its pavement seemed to me a guarantee that others of my wishes would be fulfilled as well." " Who, other than Freud, dreams of places not yet visited? My answer in this book is: "all of us." And who could deny there is a deep psychic component to our travel desires and travel choices, that the other side of sightseeing is the unconscious? 